\title{
Microbiological Quality of Fresh Vegetables and Fruits Collected from Supermarkets in Istanbul, Turkey
}

\author{
Serkan Kemal Buyukunal ${ }^{1}$, Ghassan Issa ${ }^{2}$, Filiz Aksu ${ }^{3}$, Aydin Vural ${ }^{4,}$, \\ ${ }^{1}$ Istanbul Arel University, School of Health Sciences, Department of Nutrition and Dietetics, Istanbul, Turkey \\ ${ }^{2}$ Avrupa Vocational School, Culinary Programme, Istanbul, Turkey \\ ${ }^{3}$ Istanbul University, Vocational School of Veterinary Medicine, Istanbul, Turkey \\ ${ }^{4}$ Dicle University, Faculty of Veterinary Medicine, Department of Food Hygiene and Technology, Diyarbakir, Turkey
}

Email address:

avural@dicle.edu.tr (A. Vural)

\section{To cite this article:}

Serkan Kemal Buyukunal, Ghassan Issa, Filiz Aksu, Aydin Vural. Microbiological Quality of Fresh Vegetables and Fruits Collected from Supermarkets in Istanbul, Turkey. Journal of Food and Nutrition Sciences. Vol. 3, No. 4, 2015, pp. 152-159.

doi: $10.11648 /$ j.jfns.20150304.13

\begin{abstract}
Two hundred sixty one samples, collected from supermarkets in Istanbul, Turkey. All samples were analysed for aerobic mesophilic bacterial counts (AMC), aerobic psychrotrophic bacterial counts (APC), enumeration of yeasts and moulds (YM), coliforms, Escherichia coli and detection of Escherichia coli O157:H7, Salmonella spp., Listeria monocytogenes, thermotolerant Campylobacter spp. AMC ranged from 2.95 to $3.75 \log _{10} \mathrm{CFU} / \mathrm{g}$. APC ranged from 0 to $3.55 \log _{10} \mathrm{CFU} / \mathrm{g}$. The highest counts of coliforms were found in carrot, spinach, green leaf lettuce, cos lettuce and iceberg lettuce. The highest counts of YM were found in tomato, spinach, green leaf lettuce, cos lettuce and iceberg lettuce. Green leaf lettuces, cos lettuces, iceberg lettuces, spinach and carrot were highly contaminated with aerobic mesophilic $\left(3.6 \log _{10} \mathrm{CFU} / \mathrm{g}\right)$, psychrotrophic microorganisms (3.4 $\left.\log _{10} \mathrm{CFU} / \mathrm{g}\right)$, and showed a high incidence of E.coli $(41.77 \%$ of samples). Of the samples analysed, 10 (3.83\%) were Salmonella spp. positive and 17 (6.51\%) were thermotolerant Campylobacter spp. positive. None of the samples was positive for Escherichia coli O157:H7 and Listeria monocytogenes. Fresh vegetables and fruits, sold in Istanbul, Turkey, are needed to control foodborne pathogens especially Salmonellosis and Campylobacteriosis.
\end{abstract}

Keywords: Food Safety, Fresh Fruit, Microbiological Quality, Raw Vegetable

\section{Introduction}

Hygienic fresh vegetables and fruits are important components of the human diet and there is strong relationship between fresh vegetable and fruit consumption and health [1] Raw vegetables and fruits provide proteins, carbonhydrates and many vitamins, minerals which are essential in healthy human life. These commodities are convenient meal for contemporary lifestyles. Various types of fruits and raw eaten vegetables and salads are also very popular due to their attributes. In many countries, including Turkey, consumption rates of raw fruits and vegetables is increasing day by day. To prevent cancer, diabetes, heart disease, obesity and micronutrient deficiencies, joint FAO/WHO Expert Consultation Panel recommends anadequate daily intake of 400-500 $\mathrm{g}$ of fruit and vegetables [2].

Fresh produce may be contaminated with a different kind of microorganisms [3-5]. Microbial contamination can occur during any steps of the farm-to-table and this contamination can arise from environmental, animal, human sources and technological applications. Microorganisms could spread not only by direct contact, but also through air and water [6-9]. Raw eaten vegetables and fruits are consumed without enough heating process, and therefore the possibility of food poisoning and food-borne infections always exists [10]. The number of reported food-borne outbreaks associated with raw fruits and vegetables has increased in the late years. Identified outbreaks etiology has primarily bacteriological origin [11]. However, most of farmers don't still have enough information about hygienic production and good agricultural practices. This is a highly potential risk for public health. Increasing consumption of fresh produce has associated outbreaks of foodborne illnesses [5, 12, 13]. Fresh produce can be a vehicle for the contamination of enterotoxigenic and enterohemorrhagic Escherichia coli [1, 10, 14-16], Salmonella spp. [1, 14, 17], Listeria monocytogenes [1, 17, 18, 19], thermotolerant Campylobacter spp. [20, 21], 
parasitic and viral pathogens capable of causing human illness and a number of reports refer to raw vegetables and fruits harbouring potential foodborne pathogens $[3,13,16$, 22-25].

The Centers for Disease Control and Prevention has reported an increase of fresh produce related foodborne disease outbreaks between 1995 and 2005 around the world [26].

Istanbul which has a geographic and geopolitics importance due to representing a transit corridor between Europa and Asia is a rapidly developing market cause of high population growth rate and continuous migration from various regions of Turkey and the neighboring countries. This high density of the population is regarded as a comprehensive supply of foods. Especially, the rapid growth of supermarkets chains in Turkey over the past ten years and also the subsequent development of quality requirements like volume, regularity, quality homogeneity, range of varieties, packaging have given rise to new market opportunities for local agriculture [27].

The present survey was intended to supply some assessment on the microbiological quality of marketed fresh vegetables and fruits in Istanbul, Turkey [28].

\section{Materials and Methods}

\subsection{Collection of Samples}

Two hundred sixty one fresh vegetables and fruits samples were analyzed between the period May 2012 and January 2013. The samples analyzed included: 161 samples of whole fresh vegetables, 100 samples of fresh fruits. Samples of all of the fresh produce sold in Istanbul were randomly purchased from different major supermarkets and local chain markets, in their original, individual packages. Production data of the samples are shown in table 1.

\subsection{Preparation for Microbial Analysis}

All samples were analysed as soon as possible after purchase. Before samples were taken out of their original packaging, the possible contact surfaces were carefully sterilised using polyurethane sponges to prevent crosscontamination. Damaged samples were discarded before analysis. For lettuce, spinach and purslane approximately 25 $\mathrm{g}$ of each sample were placed in a sterile stomacher bag and homogenized using a stomacher (Interscience - BagMixer $400 \mathrm{P}$, France) with $225 \mathrm{ml}$ of sterile $0.1 \%$ buffered peptone water (BPW) (Oxoid, Cambridge, UK) for $2 \mathrm{~min}$. For all other commodities, i.e. cucumber, tomato, green bean, squash, carrot, plum and peach each sample (whole) was aseptically transferred into a stomacher bag filled with equal weight of BPW. Each whole sample was then agitated and rubbed by hand in the stomacher bag for 2 min to suspend surface microbes [23, 29]. Appropriate 1:10 dilutions of the resultant homogenate or the rinse fluid were prepared using BPW.

\subsection{Aerobic Mesophilic Plate Count and Aerobic Psychrotrophic Plate Count}

Laboratory analyses to enumarate of aerobic mesophilic plate count and psychrotrophic plate count were performed in accordance with the ISO 4833-1:2003 standard [30] and ISO 17410:2001 [31], respectively.

\subsection{Enumeration of Yeasts and Moulds}

Laboratory analyses to enumarate of yeasts and moulds were performed in accordance with the ISO 7954:1987 standard [32].

\subsection{Enumeration of Coliforms and Escherichia coli}

Samples were prepared as described above. Homogenate or the rinse fluid was prepared using BPW. For each selected dilution, $0.1 \mathrm{ml}$ of sample was spread-plated onto brilliance E. coli/coliform agar (Oxoid, Cambridge, UK). The plates were incubated at $37^{\circ} \mathrm{C}$ for $24 \mathrm{~h}$, following which, the number of pink (coliform) and purple (presumptive E. coli) colonies was counted [33]. Identification of E. coli was carried out with IMVIC tests [34].

\subsection{Isolation of E. coli O157:H7}

Samples were prepared as described above. Homogenate or the rinse fluid was prepared using BPW. Laboratory analyses to detect of E. coli O157:H7 were performed in accordance with the ISO 16654:2001 standard [35)].

\subsection{Isolation of Salmonella Spp.}

Samples were prepared as described above. Laboratory analyses to detect of Salmonella spp. were performed in accordance with the ISO 6579:2002 standard [36].

\subsection{Isolation of Listeria monocytogenes}

Samples were prepared as described above. Laboratory analyses to detect of $L$. monocytogenes were performed in accordance with the ISO 11290 method [37].

\subsection{Isolation and Confirmation of Thermotolerant Campylobacter spp.}

Laboratory analyses to detect thermotolerant Campylobacter spp. were performed in accordance with the ISO 10272-1:2006 standard (qualitative analysis) [38]. To confirm suspect isolates polymerase chain reaction (PCR) methods [39] and a commercially available real-time PCR kit (Taq Man Campylobacter spp. Kit, AB Applied Biosystems) were applied. For quality control, the C. jejuni ATCC 33560 reference strain was used.

\subsection{Confirmation of Presumptive Colonies}

$\mathrm{API}^{\circledR}$ (bioMerieux, Marcy-l'Etoile, France) was used for the confirmation of presumptive colonies. The biochemical tests were carried out according to the manufacturer's instructions. 


\subsection{Statistical Analysis}

Colony counts were converted into $\log _{10} \mathrm{CFU} / \mathrm{g}$. The mean values obtained from the microbiological evaluation of fruits and vegetables were analysed by independent samples $t$-test and to determine any statistically significant difference $(P<0.05)$ among the all commodities means by one-way analysis of variance (ANOVA) followed by post hoc Tukey's test using SPSS 17.0 software (SPSS Inc. Chicago, IL, USA).

Table 1. Data on production of the samples.

\begin{tabular}{|c|c|c|c|c|}
\hline samples & production region & production area & source of water & method of irrigation \\
\hline Green leaf lettuce $^{a}$ & Antalya $^{\mathrm{b}}$ & greenhouse & ground water & drip \\
\hline Iceberg lettuce $^{a}$ & Antalya ${ }^{b}$ & greenhouse & ground water & drip \\
\hline Cos lettuce $^{\mathrm{a}}$ & Antalya ${ }^{b}$ & greenhouse & ground water & drip \\
\hline Spinach $^{\mathrm{a}}$ & Eskişehir $^{\mathrm{c}}$ & greenhouse & ground water & drip \\
\hline Purslane $^{\mathrm{a}}$ & Eskişehir $^{\mathrm{c}}$ & greenhouse & ground water & drip \\
\hline Cucumber & Antalya-Demre ${ }^{\mathrm{b}}$ & greenhouse & ground water & drip \\
\hline Tomato & Antalya-Demre ${ }^{b}$ & greenhouse & ground water & drip \\
\hline Kidney bean & Antalya-Serik ${ }^{\mathrm{b}}$ & greenhouse & ground water & drip \\
\hline Squash & Antalya-Demre ${ }^{b}$ & greenhouse & ground water & drip \\
\hline Eggplant & Antalya-Aksu ${ }^{\mathrm{b}}$ & greenhouse & ground water & drip \\
\hline Pepper & Antalya-Demre $^{\mathrm{b}}$ & greenhouse & ground water & drip \\
\hline Carrot & Sakarya $^{c}$ & field & river & aerosolization \\
\hline Plum & Antalya-Serik ${ }^{\mathrm{b}}$ & field & ground water & drip \\
\hline Apricot & Malatya-Arapgir ${ }^{\mathrm{c}}$ & field & ground water & drip \\
\hline Pear & Antalya-Serik ${ }^{\mathrm{b}}$ & field & ground water & drip \\
\hline Grape & Antalya-Serik ${ }^{\mathrm{b}}$ & field & ground water & drip \\
\hline Strawberry & Antalya-Serik $^{\mathrm{b}}$ & greenhouse & ground water & drip \\
\hline
\end{tabular}

${ }^{a}$ Untreated bovine or ovine originated manure are applied during pre-harvest on the greenhouse

${ }^{\mathrm{b}}$ Mediterranean climatic condition (mildly during spring, autumn and winter seeasons, hot and dry during summer season)

${ }^{\mathrm{c} C}$ Coldly during spring, autumn and winter seasons, hot and dry during summer season)

\section{Results}

AMC, APC and YM counts are shown in table 2. Coliform and Escherichia coli counts and percentages are shown in table 3. Results of incidence of Escherichia coli O157:H7, Salmonella spp., Listeria monocytogenes and thermotolerant Campylobacter spp.in the samples analysed are shown in table 4.

AMC and APC were up to 3.75 and $3.55 \log _{10} \mathrm{CFU} / \mathrm{g}$. Coliform and Escherichia coli counts were up to 3.45 and $2.65 \log _{10} \mathrm{CFU} / \mathrm{g}$. Escherichia coli contamination was highest in green leaf lettuce $(80 \%)$. The highest YM counts were detected in tomatoes (3.15 $\log _{10} \mathrm{CFU} / \mathrm{g}$ ). Statistically, whole fresh vegetable samples had significantly higher microbial loads than fresh fruit samples $(p<0.05)$ and green leaf lettuce, iceberg lettuce, cos lettuce and spinach had significantly higher microbial loads than other commodities $(p<0.05)$. No pathogenic bacteria could be isolated from fresh fruit samples, purslane, cucumber, tomato, green bean, kidney bean, squash, eggplant, and pepper. Salmonella spp. was isolated from 10 whole fresh vegetable samples. Thermotolerant Campylobacter spp. was isolated from 17 whole fresh vegetable samples.

Table 2. The presence of aerobic mesophilic count (AMC), aerobic phsychrotrophic count (APC) and yeasts and moulds (YM) in the samples analyzed (log 10 CFU/g).

\begin{tabular}{|c|c|c|c|c|c|c|c|}
\hline Type of samples & $n$ & AMC/g & & APC/g & & $\mathbf{Y M} / \mathbf{g}$ & \\
\hline & & range & median & range & median & range & median \\
\hline Green leaf lettuce & 15 & $3.6-3.75$ & 3.7 & $3.4-3.45$ & 3.45 & $2.95-3.05$ & 3.0 \\
\hline Iceberg lettuce & 15 & $3.5-3.65$ & 3.5 & $3.3-3.5$ & 3.35 & $2.9-3.05$ & 3.0 \\
\hline Cos lettuce & 16 & $3.5-3.6$ & 3.6 & $3.35-3.5$ & 3.4 & $2.95-3.05$ & 2.95 \\
\hline Spinach & 19 & $3.3-3.6$ & 3.5 & $3.1-3.55$ & 3.4 & $2.9-3.05$ & 2.95 \\
\hline Purslane & 14 & $3.4-3.45$ & 3.45 & $3.25-3.35$ & 3.3 & $2.8-2.95$ & 2.85 \\
\hline Cucumber & 10 & $3.2-3.35$ & 3.3 & $2.95-3.2$ & 3.05 & $2.6-2.8$ & 2.65 \\
\hline Green bean & 11 & $3-3.2$ & 3.1 & $2.6-2.85$ & 2.8 & $2.5-2.8$ & 2.6 \\
\hline Kidney bean & 11 & $2.95-3.1$ & 3.05 & $2.55-2.8$ & 2.65 & $2.5-2.8$ & 2.65 \\
\hline Squash & 10 & $3-3.2$ & 3.1 & $2.55-2.65$ & 2.6 & $2.5-2.8$ & 2.55 \\
\hline Eggplant & 10 & $2.95-3.1$ & 3.05 & $2.55-2.65$ & 2.6 & $2.5-2.8$ & 2.6 \\
\hline Pepper & 11 & $3.05-3.2$ & 3.1 & $2.55-2.65$ & 2.6 & $2.5-2.8$ & 2.55 \\
\hline Carrot & 14 & $3.6-3.75$ & 3.7 & $3.4-3.45$ & 3.45 & $2.4-2.8$ & 2.65 \\
\hline Plum & 12 & $2.95-3.1$ & 3.1 & $0-2.5$ & 2 & $2.55-2.8$ & 2.55 \\
\hline
\end{tabular}




\begin{tabular}{|c|c|c|c|c|c|c|c|}
\hline Type of samples & $n$ & $\mathrm{AMC} / \mathrm{g}$ & & APC/g & & $\mathbf{Y M} / \mathbf{g}$ & \\
\hline & & range & median & range & median & range & median \\
\hline Peach & 12 & $2.95-3.35$ & 3.1 & $0-2.85$ & 2 & $2.5-2.8$ & 2.6 \\
\hline Apple & 12 & $3.3-3.5$ & 3.35 & $0-3.45$ & 2 & $2.3-2.7$ & 2.5 \\
\hline Pear & 14 & $3.25-3.5$ & 3.3 & $0-3.5$ & 2.3 & $2.3-2.7$ & 2.4 \\
\hline Grape & 14 & $3.3-3.35$ & 3.3 & $0-2.7$ & 1 & $0-2.2$ & 0.7 \\
\hline Strawberry & 18 & $3.3-3.35$ & 3.3 & $2-2.65$ & 2.3 & $2-2.65$ & 2.2 \\
\hline Total & 261 & 2.95-3.75 & 3.45 & $0-3.55$ & 2.8 & 0-3.15 & 2.65 \\
\hline
\end{tabular}

Table 3. The presence of coliform and E.coli in thesamples analyzed.

\begin{tabular}{lllllll}
\hline Type of samples & $\boldsymbol{n}$ & \multicolumn{2}{c}{ Coliform count $\left(\mathbf{l o g}_{\mathbf{1 0}} \mathbf{C F U} / \mathbf{g}\right)$} & \multicolumn{2}{c}{ E.coli count E.coli presence $\left(\mathbf{l o g}_{\mathbf{1 0}} \mathbf{C F U} / \mathbf{g}\right)$} \\
\hline Green leaf lettuce & & range & median & range & median & number of positive samples(\%) \\
Iceberg lettuce & 15 & $3.25-3.45$ & 3.3 & $0-2.65$ & 2.5 & $12(80)$ \\
Cos lettuce & 15 & $3.25-3.45$ & 3.35 & $0-2.55$ & 2.25 & $7(46.67)$ \\
Spinach & 16 & $3.2-3.4$ & 3.3 & $0-2.6$ & 2.35 & $9(56.25)$ \\
Purslane & 19 & $2.95-3.45$ & 3.2 & $0-2.5$ & 0 & $4(21.05)$ \\
Cucumber & 14 & $2.95-3.05$ & 3 & 0 & 0 & 0 \\
Tomato & 10 & $2.7-2.85$ & 2.8 & 0 & 0 & 0 \\
Green bean & 11 & $2.9-3.1$ & 2.95 & 0 & 0 & 0 \\
Kidney bean & 11 & $2.3-2.8$ & 2.7 & 0 & 0 & 0 \\
Squash & 11 & $2.5-2.8$ & 2.55 & 0 & 0 & 0 \\
Eggplant & 10 & $2.5-2.8$ & 2.7 & 0 & 0 & 0 \\
Pepper & 10 & $2.5-2.8$ & 2.55 & 0 & 0 & 0 \\
Carrot & 11 & $2.5-2.8$ & 2.7 & 0 & 0 & 0 \\
Plum & 14 & $3.25-3.45$ & 3.25 & $0-2.3$ & 0 & $1(7.14)$ \\
Apricot & 12 & $0-2.3$ & 0 & 0 & 0 & 0 \\
Peach & 12 & $0-2.3$ & 0 & 0 & 0 & 0 \\
Apple & 12 & $0-2.3$ & 0 & 0 & 0 & 0 \\
Pear & 12 & $2.5-2.9$ & 2.7 & 0 & 0 & 0 \\
Grape & 14 & $2.6-2.9$ & 2.65 & 0 & 0 & 0 \\
Strawberry & 14 & $0-2.3$ & 0 & 0 & 0 & 0 \\
Total & 18 & $0-2.3$ & 0 & 0 & 0 & 0 \\
\hline
\end{tabular}

Table 4. The incidence of Escherichia coli O157:H7, Salmonella spp., Listeria monocytogenes and thermotolerant Campylobacter spp. in the samples analysed.

\begin{tabular}{|c|c|c|c|c|c|}
\hline \multirow[b]{2}{*}{ Type of samples } & \multicolumn{5}{|c|}{ Number and percentage (\%) of positive samples } \\
\hline & $n$ & E.coli O157:H7 & Salmonella spp. & Listeria monocytogenes & Campylobacter spp. \\
\hline Green leaf lettuce & 15 & nd & $4(26.67)$ & nd & $5(33.33)$ \\
\hline Iceberg lettuce & 15 & nd & $1(6.67)$ & nd & $4(26.67)$ \\
\hline Cos lettuce & 16 & nd & $3(18.75)$ & nd & $4(25)$ \\
\hline Spinach & 19 & nd & $1(5.26)$ & nd & $3(15.79)$ \\
\hline Purslane & 14 & nd & nd & nd & nd \\
\hline Cucumber & 10 & nd & nd & nd & nd \\
\hline Tomato & 11 & nd & nd & nd & nd \\
\hline Green bean & 11 & nd & nd & nd & nd \\
\hline Kidney bean & 11 & nd & nd & nd & nd \\
\hline Squash & 10 & nd & nd & nd & nd \\
\hline Eggplant & 10 & nd & nd & nd & nd \\
\hline Pepper & 11 & nd & nd & nd & nd \\
\hline Carrot & 14 & nd & $1(7.14)$ & nd & $1(7.14)$ \\
\hline Plum & 12 & nd & nd & nd & nd \\
\hline Apricot & 12 & nd & nd & nd & nd \\
\hline Peach & 12 & nd & nd & nd & nd \\
\hline Apple & 12 & nd & nd & nd & nd \\
\hline Pear & 14 & nd & nd & nd & nd \\
\hline Grape & 14 & nd & nd & nd & nd \\
\hline Strawberry & 18 & nd & nd & nd & nd \\
\hline Total & 261 & nd & $10(3.83)$ & nd & $17(6.51)$ \\
\hline
\end{tabular}

Abbrevations: n, number of samples; nd: not detected

\section{Discussion}

Fresh vegetables and fruits can be contaminated with pathogenic bacteria in any steps of all the process from cultivation to consuming. These bacteria cause major public health concern worldwide in terms of human ilnesses. In addition, food-borne diseases have a large economic loss. Different studies on this subject are available in the world. 
But in our country, number and content of the study is not satisfactory. Our study was planned for this reason. The AMC for the whole vegetables and fresh fruits examined was around $3.35 \log _{10} \mathrm{CFU} / \mathrm{g}$, with a range of 2.95-3.75 $\log _{10}$ $\mathrm{CFU} / \mathrm{g}$ and $3.30 \log _{10} \mathrm{CFU} / \mathrm{g}$, with a range of 2.95-3.50 $\log _{10}$ $\mathrm{CFU} / \mathrm{g}$, respectively. Pianetti et al. [40] reported that aerobic colony count does not relate to food poisoning and infections, generally. However, it acts as an indicator for food quality and shelf life.

According to the HACCP-TQM technical guidelines, raw foods containing $<10^{4} \mathrm{CFU} / \mathrm{g}\left(<4 \log _{10} \mathrm{CFU} / \mathrm{g}\right), 10^{4}-5 \times 10^{6}$ CFU/g (4-6.7 $\left.\log _{10} \mathrm{CFU} / \mathrm{g}\right), 5 \times 10^{6}-5 \times 10^{7} \mathrm{CFU} / \mathrm{g}$ (6.7-7.7 $\left.\log _{10} \mathrm{CFU} / \mathrm{g}\right)$ and $>5 \times 10^{7} \mathrm{CFU} / \mathrm{g} \quad\left(>7.7 \quad \log _{10} \mathrm{CFU} / \mathrm{g}\right)$ (number of spoilage microorganisms aerobic plate count at $70^{\circ} \mathrm{F}\left(21.1^{\circ} \mathrm{C}\right)$ are rated as "good", "average", "poor" and "spoiled food", respectively (41). In our study, the quality of 261 samples was regarded as "good".

Aycicek et al. [10] reported some raw eaten vegetables (lettuce, cos lettuce, iceberg lettuce, parsley, dill, carrot) total aerobic counts between 0 and $7.4 \log _{10} \mathrm{CFU} / \mathrm{g}$. Abadias et al. [1] found the AMC ranged from 4.3 to $8.9 \log _{10} \mathrm{CFU} / \mathrm{g}$ in fresh-cut vegetables, from 2.0 to $7.1 \log _{10} \mathrm{CFU} / \mathrm{g}$ in fresh-cut fruits, from 7.1 to $9.2 \log _{10} \mathrm{CFU} / \mathrm{g}$ in sprouts and from 2.7 to $8 \log _{10} \mathrm{CFU} / \mathrm{g}$ in whole vegetables. APC counts were similar to those of mesophilic microorganism, with carrot (7.9 $\log _{10}$ $\mathrm{CFU} / \mathrm{g})$ and spinach $(7.4 \log 10 \mathrm{CFU} / \mathrm{g})$ being the vegetables with the highest mean counts. Badosa et al. [17] reported fruits had AMC ranging from 1 to $8 \log _{10} \mathrm{CFU} / \mathrm{g}$, most of them ranging between 3 and $4 \log _{10} \mathrm{CFU} / \mathrm{g}$. Oliveira et al. [15] noted thatthe AMC ranged from $<3$ to $7 \log _{10} \mathrm{CFU} / \mathrm{g}$ in conventional and from 5 to $>7 \log _{10} \mathrm{CFU} / \mathrm{g}$ in organic lettuce. Psychrotrophic microorganism is very similar to those of mesophilic microorganisms, with ranges between 3 to $>7$ $\log _{10} \mathrm{CFU} / \mathrm{g}$ in organic lettuce and between $<3$ to $7 \log _{10}$ $\mathrm{CFU} / \mathrm{g}$ in conventional lettuce. Seow et al. (23) reported that AMC of fresh vegetables and fruits counts ranged from 1.6 to $9.1 \log _{10} \mathrm{CFU} / \mathrm{g}$ with the lowest counts recorded for orange and highest counts recorded for bean sprouts. Fresh-cut salads had the highest mean APC of $4.9 \log _{10}$ CFU/g. In another study done by Viswanathan and Kaur [14], it was reported that AMC for raw salad vegetables, fruits and sprouts were in the range between 5-10 $\log _{10} \mathrm{CFU} / \mathrm{g}, 6-8$ $\log _{10} \mathrm{CFU} / \mathrm{g}$ and 9-12 $\log _{10} \mathrm{CFU} / \mathrm{g}$, respectively. These findings were higher than our study. These differences may be originated from regions, geographical and climatical conditions, irrigation techniques and post-harvest processes.

Regarding the YM range of fresh produces, our findings is similar to other author's studies. Generally, lettuces, tomatoes and carrots contamination is higher than the other commodities for YM. Abadias et al. [1] found that the ranges for YM in fresh-cut vegetables, fresh-cut fruit, sprouts and whole vegetables were 2.0-7.8, 1.7-4.9, 2.8-7.6 and 2.2- 6.1 $\log _{10} \mathrm{CFU} / \mathrm{g}$, respectively. Grated carrot was the highest mean counts for YM (6.1 $\left.\log _{10} \mathrm{CFU} / \mathrm{g}\right)$. Oliveira et al. [15] reported that $51.4 \%$ of the organic lettuce, $52.8 \%$ conventional lettuce was found in the range between 4 and $5 \log _{10} \mathrm{CFU} / \mathrm{g}$, respectively. The YM mean was 4.7 and $4.2 \log _{10} \mathrm{CFU} / \mathrm{g}$.
Tournas (4) noted that YM counts ranged between 3.1-5.95 $\log _{10} \mathrm{CFU} / \mathrm{g}$ in lettuce, <2-5.3 $\log _{10} \mathrm{CFU} / \mathrm{g}$ in carrots, $2-3.8$ $\log _{10} \mathrm{CFU} / \mathrm{g}$ in cucumbers, 4-4.1 $\log _{10} \mathrm{CFU} / \mathrm{g}$ in iceberg lettuce, 3.4-3.6 $\log _{10} \mathrm{CFU} / \mathrm{g}$ in spinach, 2-6.2 $\log _{10} \mathrm{CFU} / \mathrm{g}$ in different kind of tomatoes (cherry, grape, Roma). Tournas [4] and Tournas and Katsoudas [42] declared the some health problems related with the presence of yeasts and moulds in vegetables and fruits. Some of these may produce mycotoxins and others are known to cause allergic reactions.

Aycicek et al. [10] found coliform counts up to $6.9 \log _{10}$ $\mathrm{CFU} / \mathrm{g}$, E.coli counts up $3.8 \log _{10} \mathrm{CFU} / \mathrm{g}$. Microbial loads of outer leaves of lettuce, cos lettuce and icerberg lettuce, parsley and dill samples detected the same levels. E.coli positive sample percentages of raw eaten vegetable was among 10\% (iceberg lettuce and carrot)-70\% (parsley). Seow et al. [23] noted that highest level of coliforms was found in bean sprouts and fresh-cut salads. Viswanathan and Kaur [14] found coliform counts ranged between 6-9 $\log _{10} \mathrm{CFU} / \mathrm{g}$ in raw salad vegetables, 4-7 $\log _{10} \mathrm{CFU} / \mathrm{g}$ in fruits and $8-11 \log _{10}$ $\mathrm{CFU} / \mathrm{g}$ in sprouts, respectively. Also, it was reported that prevalances of E.coli $50 \%$ of lettuces and $10 \%$ of carrots in their study. Abadias et al. [1] noted that E.coli was not detected in fresh-cut fruit, but was present in $7.1 \%$ whole vegetable samples and $11.4 \%$ fresh-cut vegetable samples. Our findings about E.coli prevalences showed similarity with these results. Especially, lettuces varieties, spinach, purslane, carrot etc. are risky products. Applying agricultural techniques should be reviewed for hygienic conditions.

HACCP-TQM technical guidelines give threshold and quality levels for food-borne illness hazards according to the volunteer feeding test of healthy people groups. For, E.coli, the estimated illness dose is $6-10 \log _{10} \mathrm{CFU} / \mathrm{g}$ and suggested level of E.coli for purchasing $1 \log _{10}$ CFU/g (41). In our study, purchasing limit for E.coli was exceeded $19.76 \%$ of vegetable samples (33 of the 167). On the other hand, none of the fruit sampleswere exceeded this level.

A lot of studies were undertaken about food-borne disease related to consumption of fresh fruit and vegetable showed that the number of the outbreaks has increasing day by day. Each year millions of cases occur that most of this E.coli 0157:H7, Salmonella spp., Listeria monocytogenes, Campylobacter spp. etc. Infections cause mild ilness, severe infections and serious complications-including death [43]. Abadias et al. [1] noted that none of the fresh, minimallyprocessed fruit and vegetables, and sprouts samples was positive for E.coli O157:H7 and thermotolerant Campylobacter. Of the samples analyzed $1.3 \%$ was Salmonella spp. and $0.7 \%$ were L.monocytogenes positive. Seow et al. [23] reported that E.coli O157:H7 and Salmonella spp. was not detected in the analyzed of total 125 fresh fruits and vegetables samples. Al-Hindawi and Rished [44] reported that $7 \%$ of 43 vegetables samples were detected positive for Salmonella spp. Ercolani [45] noted that $68.3 \%$ rate of Salmonella in lettuces. Garcia-Villanova Ruiz et al. [46] reported that analyzed of 80 lettuce samples, $6.3 \%$ were positive and $5.2 \%$ of analyzed 28 spinach samples were positive for Salmonella spp. Garcia-Villanova Ruiz et al. [47] 
at the another study reported that analyzed 46 of 849 vegetables samples were detected positive Salmonella spp. Jerngklinchan and Saitanu [48] reported $8.7 \%$ rate of Salmonella in bean sprouts. Viswanathan and Kaur [14] tested of 72 vegetables and $33.3 \%$ of the samples were Salmonella spp. positive; tested of 24 fruits and $37.5 \%$ of the samples were Salmonella spp. detected positive.

In the present study E.coli O157:H7 was not detected. E.coli $0157: \mathrm{H} 7$ presents sporadically at very low levels together with very high levels of competitor organisms that's why it is very difficult to detect. Salmonella spp. contamination in lettuces, spinach and carrots may cause by the use of contaminated irrigation water and untreated bovine or ovine originated manure.

Arumugaswamy et al. [49] reported of the analyzed 22 lettuce, 5 cucumber, 7 bean sprouts sample, $22.7 \%, 80 \%$, $85 \%$ were positive for L.monocytogenes, respectively. Breer and Baumgartner [50] noted $2.3 \%$ of 263 salad vegetable samples were detective L.monocytogenes positive. De Simon et al. [51] reported the L.monocytogenes prevalence rate of $7.8 \%$ of vegetables samples in Spain. Gunasena et al. [18] reported 10 of 20 lettuce sample were positive for L.monocytogenes. Harvey and Gilmour [52] reported 25\% L. monocytogenes prevalence rate in salad vegetables in Northern Ireland. In another study was undertaken Hesick et al. [53], L.monocytogenes contamination weredetected in 2 of 92 eggplant samples. MacGowan et al. [54] noted that $6.2 \%$ L.monocytogenes prevalence rate in vegetables in UK. Wong et al. [55] reported that 6 of 49 vegetable samples were detective L.monocytogenes positive. Our findings in this study showed contrary with these studies results.

Chai et al. [56] reported that 153 of 309 vegetables samples were detected Campylobacter spp. by polimerase chain reaction (PCR) techniques. Kumar et al. [20] reported that out of 56 vegetables samples examined, two $(3.57 \%)$ revealed the presence of Campylobacter spp. Park and Sanders [57] reported that 1 of 40 leafy vegetables samples, 2 of 67 lettuce samples, 1 of 63 pepper and 2 of 60 spinach samples were positive for Campylobacter spp., respectively. Verhoeff-Bakkenes et al. [21] noted that 10 of 4691 (0.21\%) vegetables samples, 2 of $790(0.25 \%)$ fruits samples were positive for Campylobacter spp. Whyte et al. [58] reported that 2 of $279(0.72 \%)$ vegetables samples were positive for Campylobacter spp.

The most important source of the Campylobacter species is birds, rodents, sheep and cattle intestinal tracts. Agricultural areas may attack by birds during the cultivation and/or storage; use of untreated manure may be source of this contamination [59].

\section{Conclusion}

In conclusion, considering the public health, fresh fruits and vegetables are common sources for various microorganisms and also pathogenic bacteria. Therefore, it is essential to ensure applying good agricultural practices GAP(s) and good manufacturing practices GMP(s) during production. Farmers should be informed about the sources of microbial contamination and should be trained in hygienic production. It is emphasized that whole fresh vegetables and fresh fruits should be protected from contamination by human, animal and other wastes which may constitute a hazard to health of the consumer through fresh produces. The use of poor microbiological quality of irrigation water should be avoided. On the other hand, post-harvest washing of fresh vegetables and fruits with organic antimicrobial agent and use of edible coatings containing antimicrobial is an important method for pathogen reduction. Transport vehicles and warehouse should be designed specifically for the transport and storage of fruits and vegetables. Also, strict temperature control from harvesting to consumption by farmer, handler, transporter, warehouseman etc. and consumers is highly important.

\section{References}

[1] Abadias M, Usall J, Anguera M, Solsona C, Vinas I. Microbiological quality of fresh, minimally-processed fruit and vegetables, and sprouts from retail establishments. Int. $J$. Food Microbiol., 2008; 123: 121-129.

[2] Anonymous. Diet, nutrition and the prevention of chronic diseases. Report of a Joint FAO/WHO Expert Consultation, World Health Organization, Geneva. Available at: http://www.fao.org/DOCREP/005/AC911E/AC911E00.HTM, 2004.

[3] Beuchat LR. Ecological factors influencing survival and growth of human pathogens on raw fruits and vegetables. Microbes Infect., 2002; 4: 413-423.

[4] Tournas VH. Moulds and yeasts in fresh and minimally processed vegetables, fruits, and sprouts. Int. J. Food Microbiol., 2005; 99: 71-77.

[5] Berger CN, Sodha SV, Shaw RK, Griffin PM, Pink D, Hand P, Frankel G. Fresh fruit and vegetables as vehicles for the transmission of human pathogens. Environ. Microbiol., 2010; 12(9): 2385-2397.

[6] Food and Drug Administration (FDA). Analysis and evaluation of prevention control measures for the control and reduction/elimination of microbial hazardson fresh and freshcut produce, Center for Food Safety and Applied Nutrition. Available at:http://www.fda.gov/Food/FoodScienceResearch/ SafePracticesforFoodProcesses/ucm091016.htm. 2001.

[7] Zhao Y. Pathogens in fruit. In: Jonger, W. (Eds.), Improving the safety of fresh fruit and vegetables. CRC Press, Washington, DC, 2005, pp. 44-88.

[8] World Health Organisation/Food and Agriculture Organization (WHO/FAO). Microbiological hazards in fresh leafy vegetables and herbs, Microbiological risk assessment series, Meeting Report. 20, Avenue Appia CH-1211 Geneva 27, Switzerland. Available at: http://www.fao.org/ag/agn/agns/jemra/ Jemra_Report\%20on\%20fresh\%20leafy\%20vegetables\%20an d\%20herbs.pdf. 2008. 
[9] Sela S, Fallik E. Microbiological Quality and Safety of Fresh Produce. In: Florkowski WJ, Shewfelt RL, Brueckner B, Prussia SE. (Eds.), Postharvest Handling. Academic Press Inc, Philadelphia, PA, 2009. p.351-398.

[10] Aycicek H, Oguz U, Karci K. Determination of total aerobic and indicator bacteria on some raw eaten vegetables from wholesailers in Ankara, Turkey. Int. J. Hyg. Environ. Health., 2006; 209: 197-201.

[11] Buck JW, Walcott RR, Beuchat LR. Recent trends in microbiological safety of fruits and vegetables. Plant Health Progress DOI: 10.1094/PHP-2003-0121-01-RV (electronic journal), 2003.

[12] Brackett RE. Incidence, contributing factors, and control of bacterial pathogens in produce. Postharvest Biol. Tec., 1999; 15: 305-311.

[13] Warriner K, Huber A, Namvar A, Fan W, Dunfield K. Recent advances in the microbial safety of fresh fruits and vegetables. Adv. Food Nutr. Res., 2009; 57: 155-208.

[14] Viswanathan P, Kaur R. Prevalance and growth of pathogens on salad vegetables, fruits, and sprouts. Int. J. Hyg. Envir. Heal., 2001; 203: 205-213.

[15] Oliveira M, Usall J, Vinas I, Anguera M, Gatius F, Abadias M. Microbiological quality of fresh fresh lettuce from organic and conventional production. Food Microbiol., 2010; 27: 679-684.

[16] Gemmell ME, Schmidt S. Microbiological assessment of river water used for the irrigation of fresh produce in a sub-urban community in Sobantu, South Africa. Food Res. Int., 2012; 47: 300-305.

[17] Badosa E, Trias R, Pares D, Pla M, Montesinos E. Microbiological quality of fresh fruit and vegatable products in Catalonia (Spain) using normalised plate-counting methods and real time polymerase chain reaction (QPCR). J. Sci. Food Agr., 2008; 88: 605-611.

[18] Gunasena DK, Kodikara CP, Ganepola K, Widanaparthirana S Occurrence of Listeria monocytogenes in food in Sri Lanka. $J$. Nat. Sci. Council, 1995; 23: 107-114.

[19] Johnston LM, Jaykus LA, Moll D, Martinez MC, Anciso J, Mora B, Moe CL. A field study of the microbiological quality of fresh produce of domestic and Mexican origin. Int. J. Food Microbiol., 2006; 112: 83-95.

[20] Kumar A, Agarwal RK, Bhilegaonkar KN, Shome BR, Bachhil VN. Occurence of Campylobacter jejuni in vegetables. Int. J. Food Microbiol., 2001; 67: 153-155.

[21] Verhoeff-Bakkenes L, Jansen HAPM, in't Veld PH, Beumer $\mathrm{RR}$, Zwietering $\mathrm{MH}$, van Leusden FM. Consumption of raw vegetables and fruits: A risk factor for Campylobacter infections. Int. J. Food Microbiol., 2011; 144: 406-412.

[22] Erkan ME, Vural A. Investigation of microbial quality of some leafy green vegetables. J. Food Technol., 2008; 6(6): 285-288.

[23] Seow J, Agoston R, Phua L, Yuk HG. Microbiological quality of fresh vegetables and fruits sold in Singapore. Food Control, 2012; 25: 39-44.

[24] Abadias M, Alegre I, Oliveira M, Altisent R, Vinas I. Growth potential of Escherichia coli $\mathrm{O} 157: \mathrm{H} 7$ on fresh-cut fruits (melon and pineapple) and vegetables (carrot and escarole) stored under different conditions. Food Control, 2012; 27: 3744.
[25] Allen KJ, Kovacevic J, Cancarevic A, Wood J, Xu J, Gill B, Allen JK, Mesak LR. Microbiological survey of imported produce available at retail across Canada. Int. J. Food Microbiol., 2013; 162: 135-142.

[26] Johnston LM, Jaykus LA, Moll D, Martinez MC, Anciso J, Mora B, Moe CL. A field study of the microbiological quality of fresh produce. J. Food Protect., 2005; 68(9): 1840-1847.

[27] Lemeilleur S, Codron JM. Marketing cooperative vs. commission agent: The Turkish dilemma on the modern fresh fruit and vegetable market. Food Policy, 2011; 36: 272-279.

[28] Anonymous. The results of address based population registration system. The Turkish Statistical Institute. Available at: http://www.turkstat.gov.tr/ PreHaber Bultenleri. do? id $=13425,2013$.

[29] Food and Drug Administration (FDA). Bacteriological Analytical Manual [online](8th edition.). Available at: http://www.fda.gov/Food/ScienceResearch/ LaboratoryMethods/BacteriologicalAnalyticalManualBAM/de fault.htm, 1998.

[30] Anonymous. Microbiology of food and animal feeding stuffs-Horizontal methods for the enumeration of microorganisms. Colony-count technique at $30{ }^{\circ} \mathrm{C}$.. ISO 4833:2003, International Organization for Standardization, Geneva, Switzerland, 2003.

[31] Anonymous. Microbiology of food and animal feeding stuffs-Horizontal methods for the enumeration of psychrotrophic microorganisms. ISO 17410:2001, International Organization for Standardization, Geneva, Switzerland, 2001b.

[32] Anonymous. Microbiology of food and animal feeding stuffsEnumeration of yeasts and mould. ISO 7954:1987, International Organization for Standardization, Geneva, Switzerland, 1987.

[33] Frampton EW, Restaino L, Blaszko N. Evaluation of the $\beta$ glucuronidasesubstrate 5-bromo-4-chloro-3-indolyl- $\beta$-Dglucuronide (X-GLUC) in a 24-hour direct plating method for Escherichia coli. J. Food Protect., 51(5): 402-404, 1988.

[34] Andrews W. Manual of food quality control 4. Chapter 3, Microbiological Analysis (rev. 1). Food and Drug Administration, FAO Consultant, Washington, DC, 1992.

[35] Anonymous. Microbiology of Food and Animal Feeding stuffs - Horizontal Method for the Detection of Escherichia coli O157. ISO 16654:2001, International Organization for Standardization, Geneva, Switzerland, 2001a.

[36] Anonymous. Microbiology of Food and Animal Feeding Stuffs-Horizontal Method for the Detection of Salmonella spp. ISO 6579:2002, International Organization for Standardization, Geneva, Switzerland, 2002.

[37] Anonymous. Microbiology of food and animal feeding stuffs - Horizontal method for the detection and enumeration of Listeria monocytogenes. ISO 11290, International Organization for Standardization, Geneva, 1996.

[38] Anonymous. Microbiology of Food and Animal feeding Stuffs-Horizontal Method for Detection and Enumeration of Campylobacter spp. ISO 10272-1:2006, International Organisation for Standardisation, International Organization for Standardization, Geneva, Switzerland, 2006. 
[39] Lund M, Nordentoft S, Pedersen K, Madsen M. Detection of Campylobacter spp. in chicken fecal samples by real-time PCR. J. Clin. Microbiol., 2004; 42: 5125-5132.

[40] Pianetti A, Sabatini L, Citterio B, Pierfelici L, Ninfali P, Bruscolini F. Changes in microbial populations in ready-to-eat vegetable salads during shelflife. Ital. J. Food Sci., 20: 245254, 2008.

[41] Anonymous. HACCP-TQM Technical guidelines. Section IV Contamination levels and microbiological control. Available at: http://www.hi-tm.com/PDG/Tech-Sect-4.html, 1998.

[42] Tournas VH, Katsoudas E. Mould and yeast flora in fresh berries, grapes and citrus fruits. Int. J. Food Microbiol., 2005; 105: 11-17.

[43] Notermans S, Gallhoff G, Zweitering M, Mead G. Identification of critical control points in the HACCP system with a quantitative effect on the safety of food products. Food Microbiol., 12: 93-98, 1995.

[44] Al-Hindawi N, Rished R. Presence and distribution of Salmonella species in some local foods from Baghdad City, Iraq. J. Food Protect., 1979; 42: 877-880.

[45] Ercolani GL. Bacteriological quality assesment of fresh marketed lettuce and fennel. Appl. Environ. Microb., 1976; 31: 847-852.

[46] Garcia-Villanova Ruiz B, Galvez Vargas R, Garcia-Villanova R. Contamination on fresh vegetables during cultivation and marketing. Int. J. Food Microbiol., 1987a; 4: 285-291.

[47] Garcia-Villanova Ruiz B, Cuetoespinaz A, Bolonos MJ. A comparative study of Salmonella isolated from irrigation waters, vegetables and human infections. Epidemiol. Infect., 1987b; 98: 271-276.

[48] Jerngklinchan J, Saitanu K. The occurrence of salmonellae in bean sprouts in Thailand. Southeast Asian J. Trop. Med. Public Health, 1993; 25: 114-118.

[49] Arumugaswamy RKG, Rahamat RAG, Nadzriah BAHS Prevalance of Listeria monocytogenes in foods in Malaysia. Int. J. Food Microbiol., 1994; 23: 117-121.
[50] Breer C, Baumgartner A. Occurence and behavior of Listeria monocytogenes in salads, vegetables, and fresh vegetables juice. Arch. Lebensmittelhyg. 1992; 43: 108-110.

[51] De Simon M, Tarrago C, Ferrer MD. Incidence of Listeria monocytogenes in fresh foods in Barcelona (Spain). Int. J. Food Microbiol., 1992; 16: 153-156.

[52] Harvey J, Gilmour A. Occurence and characteristics of Listeria in foods produced in Nothern Ireland. Int. J. Food Microbiol., 1993; 19: 193-205.

[53] Heisick JE, Wagner DE, Nierman ML, Peeler JT. Listeria spp. found on fresh market produce. Appl. Environ. Microb., 1989; 55: $1925-1927$.

[54] MacGowan AP, Bowker K, McLauchlin J, Bennet PM, Reeves DS. The occurence and seasonal changes in the isolation of Listeria spp. in shop bought food stuffs, human faeces, sewage and soil from urban sources. Int. J. Food Microbiol., 1994; 21: 325-334.

[55] Wong HC, Chao WL, Lee SJ. Incidence and characterization of Listeria monocytogenes in foods available in Taiwan. Appl. Environ. Microb., 1990; 56: 3101-3104.

[56] Chai LC, Robin T, Ragavan UM, Gunsalam JW, Bakar FA, Ghazali FM, Radu S, Kumar MP. Thermophilic Campylobacter spp. in salad vegetables in Malaysia. Int. J. Food Microbiol., 2007; 117: 106-111.

[57] Park CE, Sanders GW. Occurence of thermotolerant campylobacters in fresh vegetables sold at farmers outdoor markets and supermarkets. Can. J. Microbiol., 1991; 38: 313316.

[58] Whyte P, McGill K, Cowley D, Madden RH, Moran L, Scates P, Carrol C, O'Leary A, Fanning S, Collins JD, McNamara E, Moore JE, Cormican M. Occurence Campylobacter in retail foods in Ireland. Int. J. Food Micr obiol., 2004;95: 111-118.

[59] Erol İ. Gida kaynakl patojen bakteriler. In: Gida hijyeni ve mikrobiyolojisi. Pozitif Matbaacılık Ltd., Ankara, 2007, pp. 71-77. 